\title{
ANALISIS KESALAHAN SISWA DALAM MENYELESAIKAN SOAL-SOAL MATERI OPERASI BENTUK ALJABAR BERDASARKAN TAHAPAN NEWMAN DI KELAS VII SMP NU BULULAWANG
}

\author{
Intan Tria Mada Surya ${ }^{1)}$, I Ketut Suastika ${ }^{2)}$, Nyamik Rahayu Sesanti ${ }^{3)}$ \\ ${ }^{1)}$ Program Studi Pendidikan Matematika, Universitas Kanjuruhan Malang \\ ${ }^{2}$ Program Studi Pendidikan Matematika, Universitas Kanjuruhan Malang \\ ${ }^{3)}$ Program Studi Pendidikan Guru Sekolah Dasar, Universitas Kanjuruhan Malang \\ intantria56@gmail.com
}

\begin{abstract}
This study aims to describe students' mistakes in completing algebraic form operation questions based on Newman's stages. This research approach is a qualitative approach using descriptive research types. Data collection techniques were carried out by test and interview methods. The validity test of the data is done by source triangulation. The results showed that the mistakes made by students were a reading error of $44.4 \%$, understanding the problem of $72.2 \%$, transformation of $44.4 \%$, process skills of $44.4 \%$, and answer writing of $77.8 \%$. The cause of students' mistakes is because they cannot mention the keywords or symbols on the questions, students do not understand the problems that exist in the questions, students do not write down the procedures used, make mistakes in calculations so that the final answers are wrong, and errors in writing units.
\end{abstract}

Keywords - Error Analysis; Newman Stages; Algebraic Formation Operations.

Abstrak. Penelitian ini bertujuan untuk mendeskripsikan kesalahan siswa dalam menyelesaikan soal operasi bentuk aljabar berdasarkan tahapan Newman. pendekatan penelitian ini adalah pendekatan kualitatif dengan menggunakan Jenis penelitian deskriptif. Teknik pengumpulan data dilakukan dengan metode tes dan wawancara. Uji keabsahan data dilakukan dengan triangulasi sumber. Hasil penelitian menunjukkan bahwa kesalahan yang dilakukan siswa adalah kesalahan membaca sebesar $44.4 \%$, memahami soal sebesar $72.2 \%$, transformasi sebesar $44.4 \%$, ketrampilan proses sebesar $44.4 \%$, dan penulisan jawaban sebesar $77.8 \%$. Penyebab kesalahan siswa dikarenakan tidak dapat menyebutkan kata kunci atau simbol yang ada pada soal, siswa kurang memahami masalah yang ada pada soal, siswa tidak menuliskan prosedur yang digunakan, melakukan kesalahan dalam perhitungan sehingga jawaban akhir salah, dan kesalahan dalam menuliskan satuan.

Kata Kunci - Analisis Kesalahan; Tahapan Newman; Operasi Bentuk Aljabar.

\section{Pendahuluan}

Matematika merupakan ilmu yang berkaitan erat dengan kehidupan sehari-hari. Menurut Susanto (2013) matematika merupakan salah satu disiplin ilmu yang memberikan kontribusi dalam menyelesaikan masalah sehari-hari dan dalam dunia kerja. Walaupun matematika memiliki peranan penting dalam kehidupan sehari-hari, namun masih banyak siswa yang mengagap matematik sebagai pelajaran yang sulit. Menurut Hudzaifah (2013), banyak siswa masih menganggap matematika itu sulit dipahami, siswa juga menganggap bahwa matematika adalah ilmu hafalan dari sekian banyak rumus. Siswa merasa kesulitan dalam menyelesikan soal matematika sehingga banyak siswa yang melakukan kesalahan.

Salah satu materi matematika yang diajarkan di sekolah adalah aljabar. Islamiyah, dkk (2018) berpendapat bahwa aljabar merupakan materi yang penting dan berperan dalam proses pemecahan masalah matematika. Namun banyak siswa yang mengalami kesulitan dalam menyelesaikan masalah aljabar sehingga kemampuan dalam menyelesaikan masalah aljabar masih rendah (Yanto, Karniasih, dan Darmono, 2014). Oleh karena itu siswa perlu menguasai dengan baik materi dasar aljabar, yakni operasi bentuk aljabar, agar mempermudah siswa dalam mempelajari materi aljabar pada tingkat selanjutnya. Operasi bentuk aljabar menjadi prasyarat untuk materi berikutnya sehingga wajib untuk dikuasai oleh siswa kelas VII SMP. Materi berikutnya yaitu persamaan linier satu variabel, sistem persamaaan linier dua variabel, persamaan garis lurus, dan lain-lain. Akan tetapi masih banyak siswa yang belum menguasai operasi bentuk aljabar. Hasil penelitian Hasibuan (2015) menyatakan bahwa penguasaan operasi bentuk aljabar sangat rendah, yaitu hanya 3,7\% siswa yang menguasainya. Penguasaan konsep matematika perlu untuk memecahkan masalah dalam matematika (Andriani dkk, 2017). Seperti halnya siswa SMP NU bululawang yang masih

Copyright $(9) 2018$ Author [s]. This is an open-access article distributed under the terms of the Creative Commons Attribution License (CC BY). The use, distribution or reproduction in other forums is permitted, provided the original author(s) and the copyright owner(s) are cre dited and that the original publication in this journal is cited, in accordance with accepted academic practice. No use, distribution or reproduction is permitted which does not comply with these terms. 
$\mathbf{2 6} \mid \mathrm{P}$ a g e

banyak melakukan kesalahan dalam mengerjakan soal-soal berkaitan dengan aljabar dikarenakan belum menguasai operasi bentuk aljabar.

Operasi bentuk aljabar banyak ditemui pada kehidupan sehari-hari, misalnya dalam pengukuran luas tanah, menghitung selisih umur, menghitung harga barang dan lain-lain. Hal tersebut menggambarkan pentingnya operasi aljabar untuk dipelajari, sehingga dipilih materi operasi bentuk aljabar dalam penelitan ini dikarenakan pentingnya materi operasi bentuk aljabar, serta salah satu prasyarat untuk menuju materi tingkat selanjutnya.

Kesalahan yang biasa dilakukan siswa yaitu kesalahan dalam menentukan apa yang diketahui, membuat model matematika, menyelesaikan model matematika, dan jawaban akhir (Wijaya, dkk, 2013). Sebenarnya banyak kesalahan yang dilakukan oleh siswa merupakan hal yang wajar, tetapi jika kesalahan yang muncul tidak diperhatikan, maka akan berdampak buruk pada siswa. Oleh karena itu, untuk membantu mengatasi permasalahan kesalahan dalam menyelesaikan soal matematika maka perlu dilakukan analisis mengenai kesalahan-kesalahan yang dilakukan siswa. Menurut Brown dan Skow (dalam Mulyadi: 2018) analisis kesalahan telah terbukti menjadi metode yang efektif untuk mengidentifikasi kesalahan matematis siswa.

Mengidentifikasi kesalahan siswa sangat diperlukan, salah satunya dengan cara menganalisis kesalahan siswa dalam menyelesaikan soal dengan tahapan-tahapan tertentu. White (2010) menjelaskan, Newman memberikan lima kegiatan penting dalam pembelajaran untuk memunculkan kemampuan siswa dalam menyelesaikan soal uraian yang meliputi lima tahapan berikut, yaitu: (1) membaca masalah (reading), (2) memahami masalah (comprehension), (3) transformasi masalah (trasformation), (4) ketrampilan proses (process skill), dan (5) penulisan jawaban akhir (encoding).

Analisis kesalahan adalah penyelidikan terhadap suatu bentuk penyimpangan atau kekeliruan dari jawaban tertulis siswa (Rahmania, dkk 2016). Analisis kesalahan sebagai prosedur kerja mempunyai langkah-langkah tertentu (Yulia, dkk 2017). Jadi, analisis kesalahan adalah penyelidikan terhadap penyimpangan dari pekerjaan siswa dengan menggunakan tahapan-tahapan tertentu sehingga mengetahui letak kesalahan dan penyebabnya. Analisis kesalahan pada penelitian ini adalah penyelidikan terhadap penyimpangan dari pekerjaan siswa pada materi operasi bentuk aljabar berdasarkan tahapan Newman, sehingga dapat diketahui letak kesalahan siswa dan penyebabnya. Kesalahan yang dilakukan oleh siswa perlu dianalisis lebih lanjut, agar mendapat gambaran tentang kelemahan-kelemahan siswa (layn, dkk 2017). Oleh karena itu, analisis kesalahan perlu dilakukan dalam proses pembelajaran dengan menggunakan prosedur tertentu, agar mengetahui dimana letak dan penyebab terjadinya kesalahan yang dilakukan siswa sehingga dapat ditangani dengan semestinya dan meminimalisir kesalahan siswa dalam menyelesaikan soal-soal matematika khususnya materi operasi bentuk aljabar.

Pada tahun 1977 metode analisi kesalahan Newman diperkenalkan pertama kali oleh Anne Newman, seorang guru matematika di Australia. White (2010) menjelaskan, Newman memberikan lima kegiatan penting dalam pembelajaran untuk memunculkan kemampuan siswa dalam menyelesaikan soal uraian yang meliputi lima tahapan berikut, yaitu: (1) membaca masalah (reading), (2) memahami masalah (comprehension), (3) transformasi masalah (trasformation), (4) ketrampilan proses (process skill), dan (5) penulisan jawaban akhir (encoding).

Newman (dalam Oktaviana: 2017) mengemukakan bahwa ketika siswa berusaha menjawab sebuah permasalahan yang berbentuk soal uraian, maka siswa tersebut telah melewati serangkaian rintangan berupa tahapan dalam pemecahan masalah, yang meliputi: a) membaca masalah (reading), ketika seorang membaca sebuah teks, maka pembaca akan di representasikan sesuai dengan pemahamannya terhadap apa yang dibaca, selanjutnya, kemampuan membaca siswa berpengaruh terhadap bagaimana siswa tersebut akan memecahkan masalah; b) memahami masalah (comprehension), untuk mengecek kemampuan memahami masalah, siswa dimintan menyebutkan apa saja yang diketahui dan ditanyakan dalam soal; c) transformasi masalah (trasformation), untuk mengecek kemampuan untuk mentransformasikan masalah, siswa diminta menentukan prosedur atau strategi apa yang digunakan dalam menyelesaikan soal; d) ketrampilan proses (process skill), untuk mengecek keterampilan memproses, siswa diminta menyelesaikan soal sesuai prosedur matematika yang telah direncanakan pada tahapan mentransformasikan masalah; e) penulisan jawaban akhir (encoding), pada tahap ini siswa dikatakan telah mencapai tahap penulisan jawaban akhir apabila siswa mampu menuliskan jawaban secara tepat, selanjutnya untuk mengecek kemampuan penulisan jawaban, siswa diminta mengecekan kembali jawabannya dan siswa diminta menginterpretasikan jawaban akhir.

Analisis Newman dapat membantu guru mengetahui letak dan penyebab kesulitan siswa dalam belajar sehingga siswa tidak melakukan kesalahan. Menurut Karnasih (2015) Analisi Newman menyediakan kerangka kerja untuk mempertimbangkan alasan yang mendasari kesulitan dan proses belajar siswa, dan membantu guru untuk menentukan dimana letak kesalahpahaman siswa dan menentukan strategi mana dalam pengajaran yang efektif untuk mengatasinya.

Menurut Newman sebagaimana dikutip White (2010) ketika siswa ingin menemukan solusi yang tepat dari suatu masalah matematika dalam bentuk soal uraian, maka siswa dapat melakukan lima kegiatan berikut:

a. Silahkan baca soal tersebut. Jika kamu tidak mengetahui suatu kata tinggalkan saja.

b. Katakan apa pertanyaan yang diminta untuk kamu kerjakan.

c. Katakan bagaimana kamu akan menemukan jawaban.

d. Tunjukkan bagaimana cara kamu untuk memperoleh jawaban tersebut.

e. Tuliskan jawaban dari pertanyaan tersebut

Copyright (C) 2018 Author [s]. This is an open-access article distributed under the terms of the Creative Commons Attribution License (CC BY). The use,

distribution or reproduction in other forums is permitted, provided the original author(s) and the copyright owner(s) are credited and that the original publication in this journal is cited, in accordance with accepted academic practice. No use, distribution or reproduction is permitted which does not comply with these terms. 
Peneliti dalam penelitian ini menggunakan indikator kesalahan siswa dalam menyelesaikan soal uraian berdasarkan prosedur analisis kesalahan Newman dari adaptasi Yuirsa (2016) terdapat pada Tabel 1.

Tabel 1. Indikator Kesalahan Siswa Berdasarkan Prosedur Analisis Kesalahan Newman

\begin{tabular}{|c|c|c|}
\hline No & Tahapan kesalahan Newman & Indikator kesalahan \\
\hline 1. & Membaca (reading) & $\begin{array}{l}\text { a. Tidak dapat menentukan kata kunci dalam soal } \\
\text { b. Tidak dapat mengartikan kata-kata yang dianggap sulit } \\
\text { yang diajukan. }\end{array}$ \\
\hline 2. & $\begin{array}{l}\text { Memahami } \\
\text { (comprehension) }\end{array}$ & $\begin{array}{l}\text { a. Tidak menuliskan apa yang diketahui } \\
\text { b. Tidak menuliskan apa yang ditanyakan dan tidak dapat } \\
\text { menjelaskan maksud dari pertanyaan soal. } \\
\text { c. Menuliskan apa yang diketahui dengan menggunakan } \\
\text { simbol-simbol yang dibuat sendiri dan tanpa keterangan. } \\
\text { d. Menuliskan hal yang di tanyakan tapi tidak sesuai dengan } \\
\text { yang diminta soal. }\end{array}$ \\
\hline 3. & Transformasi (transformation) & $\begin{array}{l}\text { a. Tidak tepat dalam memilih operasi (rumus) atau teori yang } \\
\text { digunakan. }\end{array}$ \\
\hline 4. & $\begin{array}{l}\text { Keterampilan proses } \\
\text { (process skill) }\end{array}$ & $\begin{array}{l}\text { a. Kesalahan dalam komputasi. } \\
\text { b. Tidak tepat dalam menjelaskan proses komputasi dalam } \\
\text { lembar jawaban. } \\
\text { c. Tidak melanjutkan prosedur penyelesaian. }\end{array}$ \\
\hline 5. & Penulisan jawaban (encoding) & $\begin{array}{l}\text { a. Tidak menuliskan jawaban dan kesimpulan. } \\
\text { b. Menuliskan jawaban dan kesimpulan yang tidak tepat. } \\
\text { c. Tidak menyertakan satuan yang sesuai. }\end{array}$ \\
\hline
\end{tabular}

Sumber, adaptasi dari Yuirsa, (2016)

\section{METODE}

Penelitian ini Bertujuan untuk mengetahui secara langsung letak kesalahan siswa dalam menyelesaikan soalsoal operasi bentuk aljabar dan penyebabnya. Maka pendekatan penelitian ini adalah pendekatan kualitatif dengan menggunakan Jenis penelitian deskriptif. Sumber data dalam penelitian ini adalah kelas VII SMP NU Bululawang yang berjumlah 29 peserta yang terdiri dari 17 siswa laki-laki dan 12 siswa perempuan, akan diambil 6 subjek sebagai subjek penelitian. Prosedur pengumpulan data menggunkan metode tes dan wawancara. Tes digunakan untuk mendapatkan data kesalahan yang dilakukan siswa dalam menyelesaikan soal-soal berdasarkan tahapan Newman. Pada penelitian ini menggunakan wawancara semi tersetruktur untuk memperkuat temuan data dari hasil tes. Wawancara dilakukan pada 6 subjek penelitian yang telah ditentukan dari masing-masing kelompok yaitu 2 subjek penelitian kelompok atas (nilai tinggi), 2 subjek penelitian kelompok sedang (nilai sedang), 2 subjek penelitian kelompok rendah (nilai rendah). Berikut kriteria pengelompokan siswa berdasarkan nilai hasil tes terdapat pada Tabel 2.

Tabel 2. Kriteria Pengelompokan Siswa Berdasarkan Nilai Hasil Tes

\begin{tabular}{lll}
\hline No. & Kriteria kelompok & Rentang Nilai \\
\hline $\mathbf{1}$ & Tinggi & Nilai $\geq 76$ \\
$\mathbf{2}$ & Sedang & $52<$ Nilai $<76$ \\
$\mathbf{3}$ & Rendah & Nilai $\leq 52$ \\
\hline
\end{tabular}

Teknik analisis data yang digunakkan adalah reduksi data, penyajian data, dan penarikan kesimpulan.

Reduksi data dilakukan dengan tiga tahap yaitu 1) mengoreksi hasil tes, 2) mengelompokkan siswa kedalam 3 kelompok yaitu kelompok atas (nilai tinggi), kelompok sedang (nilai sedang), kelompok rendah (nilai rendah), kemudian akan dipilih 6 subjek penelitian untuk menjadi subjek wawancara, 3) melakukan wawancara pada subjek yang telah dipilih. Penyajian data pada penelitian ini ada 3 yaitu 1) hasil pekerjaan siswa, 2) hasil wawancara dan, 3) data analisis yang berupa kesalahan siswa dalam menyelesaikan soal-soal materi operasi bentuk aljabar berdasarkan tahapan Newman. Penarikan kesimpulan dapat dilakukan dengan mengkroscek hasil pekerjaan siswa dengan hasil wawancara sehingga dapat diketahui letak kesalahan dan penyebabnya. Keabsahan temuan menggunakan triangulasi sumber yaitu membandingkan antara hasil tes dengan hasil wawancara. Tahap-tahap penelitian ini yaitu perencanaan, pelaksanaan, dan analisis data. 


\section{A. Hasil}

\section{Hasil dan Pembahasan}

Jawaban siswa dikoreksi kemudian dikelompokkan mejadi 3 kelompok yaitu kelompok atas (nilai tinggi), kelompok sedang (nilai sedang), kelompok rendah (nilai rendah). Setelah itu Subjek penelitian diambil sebanyak 6 siswa dipilih masing-masing 2 subjek dari setiap kelompok. Daftar subjek penelitian tersaji pada Tabel 3 berikut.

Tabel 3. Daftar Subjek Penelitian

\begin{tabular}{lll}
\hline No & Siswa & Kelompok \\
\hline $\mathbf{1}$ & S5 & Atas \\
$\mathbf{2}$ & S2 & Atas \\
$\mathbf{3}$ & S1 & Sedang \\
$\mathbf{4}$ & S27 & Sedang \\
$\mathbf{5}$ & S21 & Rendah \\
$\mathbf{6}$ & S7 & Rendah
\end{tabular}

Data kesalahan yang dilakukan subjek penelitian berdasarkan tahapan Newman dalam menyelesaikan soal-soal materi operasi bentuk aljabar. Berikut data kesalahan yang dilakukan subjek penelitian terdapat pada Tabel 4.

Tabel 4. Data Kesalahan Yang Dilakukan Subjek Penelitian

\begin{tabular}{|c|c|c|c|c|c|c|}
\hline \multirow{2}{*}{ Subjek } & \multirow{2}{*}{ Soal } & \multicolumn{5}{|c|}{ Kesalahan Berdasarkan Tahapan Newman } \\
\hline & & $\mathbf{R}$ & $\mathbf{C}$ & $\mathbf{T}$ & $\mathbf{P}$ & $\mathbf{E}$ \\
\hline \multirow[t]{3}{*}{ S5 } & 1 & & $\sqrt{ }$ & & & $\sqrt{ }$ \\
\hline & 2 & & $\sqrt{ }$ & & & \\
\hline & 3 & & $\sqrt{ }$ & $\sqrt{ }$ & & \\
\hline \multirow[t]{3}{*}{$\mathbf{S 2}$} & 1 & & & & $\sqrt{ }$ & $\sqrt{ }$ \\
\hline & 2 & & & & & \\
\hline & 3 & & $\sqrt{ }$ & $\sqrt{ }$ & & $\sqrt{ }$ \\
\hline \multirow[t]{3}{*}{ S1 } & 1 & $\sqrt{ }$ & & & & $\sqrt{ }$ \\
\hline & 2 & $\sqrt{ }$ & & & & $\sqrt{ }$ \\
\hline & 3 & & $\sqrt{ }$ & $\sqrt{ }$ & & \\
\hline \multirow[t]{3}{*}{ S27 } & 1 & & & & $\sqrt{ }$ & $\sqrt{ }$ \\
\hline & 2 & & $\sqrt{ }$ & $\sqrt{ }$ & $\sqrt{ }$ & $\sqrt{ }$ \\
\hline & 3 & & $\sqrt{ }$ & $\sqrt{ }$ & & $\sqrt{ }$ \\
\hline \multirow[t]{3}{*}{ S21 } & 1 & $\sqrt{ }$ & $\sqrt{ }$ & & $\sqrt{ }$ & $\sqrt{ }$ \\
\hline & 2 & $\sqrt{ }$ & $\sqrt{ }$ & $\sqrt{ }$ & $\sqrt{ }$ & $\sqrt{ }$ \\
\hline & 3 & $\sqrt{ }$ & $\sqrt{ }$ & $\sqrt{ }$ & & $\sqrt{ }$ \\
\hline \multirow[t]{3}{*}{ S7 } & 1 & $\sqrt{ }$ & $\sqrt{ }$ & & $\sqrt{ }$ & $\sqrt{ }$ \\
\hline & 2 & $\sqrt{ }$ & $\sqrt{ }$ & & $\sqrt{ }$ & $\sqrt{ }$ \\
\hline & 3 & $\sqrt{ }$ & $\sqrt{ }$ & $\sqrt{ }$ & $\sqrt{ }$ & $\sqrt{ }$ \\
\hline
\end{tabular}

Keterangan :

$\sqrt{ }=$ melakukan kesalahan

$\mathrm{R}=$ Reading (membaca)

$\mathrm{C}=$ Comprehension (memahami masalah)

$\mathrm{T}=$ Transformation (tranformasi)

$\mathrm{P}=$ Process skill (keterampilan proses)

$\mathrm{E}=$ Encoding (penulisan jawaban) 
Persentase kesalahan berdasarkan tahapan Newman terdapat pada Tabel 5.

Tabel 5. Persentase Kesalahan Berdasarkan Tahapan Newman

\begin{tabular}{lll}
\hline No. & Kesalahan Berdasarkan Tahapan Newman & Persentase \\
\hline $\mathbf{1}$ & kesalahan membaca & 44.4 \\
\hline $\mathbf{2}$ & kesalahan memahami masalah & 72.2 \\
\hline $\mathbf{3}$ & kesalahan transformasi & 44.4 \\
\hline $\mathbf{4}$ & kesalahan keteramplan proses & 44.4 \\
\hline $\mathbf{5}$ & kesalahan penulisan jawaban akhir & 77.8 \\
\hline
\end{tabular}

\section{B. Pembahasan}

1. Kesalahan membaca

Pada hasil tes siswa belum terlihat adanya kesalahan membaca, akan tetapi pada saat dilakukan wawancara beberapa subjek penelitian melakukan kesalahan membaca diantaranya S1 pada soal nomor 1 dan 2 , S7, dan S21 pada semua soal tes. Diketahui subjek penelitian melakukan kesalahan membaca karena subjek penelitian tidak dapat menyebutkan kata kunci dalam soal atau simbol dalam soal. Hasil ini sesuai dengan penelitian Amalia, dkk (2018) bahwa faktor yang menyebabkan siswa mengalami kesalahan membaca: (1) Siswa tidak mampu mengenal simbolsimbol dalam soal, (2) Siswa tidak mampu memaknai arti setiap kata, istilah atau simbol dalam soal. Berikut contoh hasil pekerjaan S21 yang melakukan kesalahan membaca terdapat pada Gambar 1.

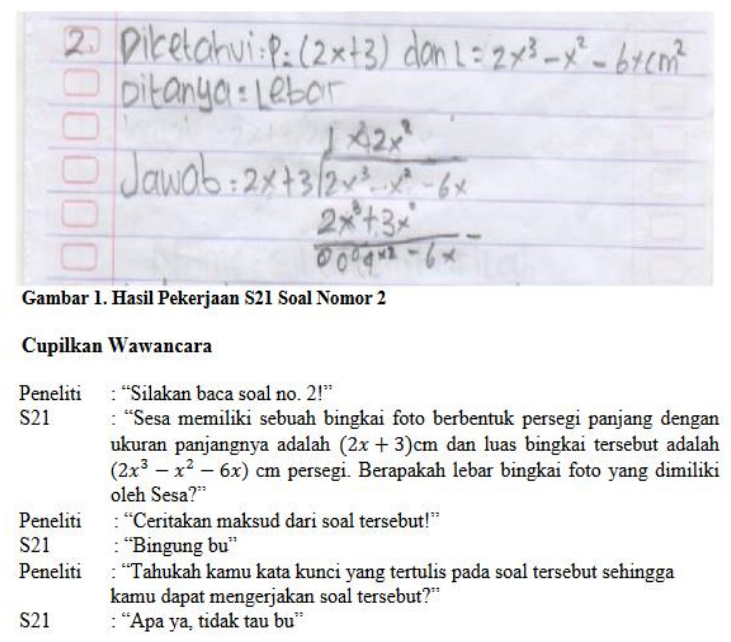

Berdasarakan hasil pekerjaan S21 pada Gambar 1 belum menunjukkan adanya kesalahan membaca, namun pada saat dilakukkan wawancara barulah terlihat bahwa S21 melakukan kesalahan membaca, dimana S21 tidak dapat menjelaskan maksud dari soal dan tidak dapat menyebutkan kata kunci yang ada pada soal.

\section{Kesalahan memahami soal}

Pada hasil tes ke 6 subjek penelitian menujukkan adanya kesalahan memahami soal, diantaranya subjek S5, S21, dan S7 pada semua soal tes, S7 pada soal nomor 2 dan 3, S1 dan S2 pada soal nomor 3. Hal tersebut telah dikonfirmasi dalam wawancara, diketahui subjek penelitian memang melakukan kesalahan memahami soal karena tidak dapat memahami masalah dalam soal sehingga tidak menuliskan apa yang diketahui atau ditanya dan menuliskan apa yang diketahui dan ditanya tetapi tidak menuliskannya secara lengkap. Hasil ini sesuai dengan penelitian Rahayuningsih, dkk (2014) bahwa penyebab siswa melakukan kesalahan pada tahap memahami soal yaitu siswa tidak menuliskan bagian yang diketahui atau ditanyakan, salah dalam menuliskan bagian tersebut, dan tidak lengkap dalam menuliskannya. Hasil ini juga sesuai dengan penelitian Islamiyah (2018) bahwa kesalahan memahami soal karena siswa tidak menuliskan hal yang diketahui dan ditanyakan.

Berikut contoh hasil pekerjaan S1 yang melakukan kesalahan pemahami soal terdapat pada Gambar 2. 


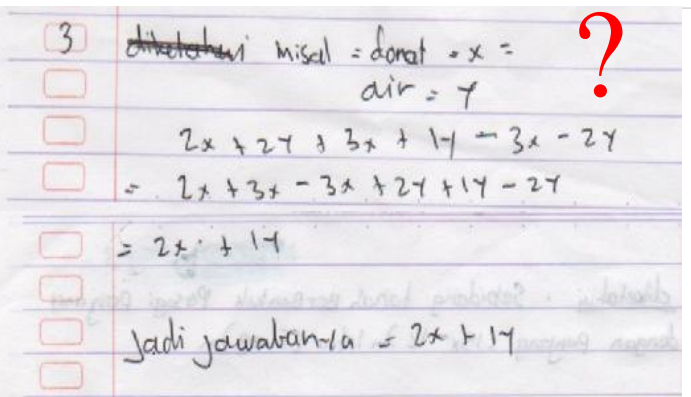

Gambar 2. Hasil Pekerjaan S1 Soal Nomor 3

Berdasarkan hasil pekerjaan S1 pada Gambar 2, menunjukkan bahwa S1 belum menuliskan apa yang diketahui dan apa yang ditanya, sehingga S1 dikatakkan melakukan kesalahan dalam memahami masalah.

\section{Kesalahan transformasi}

Pada hasil tes ke 6 subjek penelitian menujukkan adanya kesalahan tranformasi diantaranya S27 dan S21 pada soal nomor 2, ke 6 subjek penelitian pada soal nomor 3, dan tidak ada yang melakukan kesalahan transformasi pada soal nomor 1. Hal tersebut telah dikonfirmasi dalam wawancara, diketahui subjek penelitian memang mengalami kesalhan transformasi pada soal nomor 2 dan 3 karena karena tidak dapat mengidentifikasi operasi atau menentukan rumus yang dibutuhkan untuk menyelesaikan permasalahan tersebut. Sesuai dengan hasil penelitian Amalia, dkk (2018) bahwa faktor yang menyebabkan siswa mengalami kesalahan transformasi, siswa tidak mengetahui operasi hitung yang diperlukan untuk menyelesaikan soal. Hasil ini juga sesuai dengan penelitian Fatahillah, dkk (2017) bahwa siswa melakukan kesalahan transformasi karena tidak menggunakan operasi yang tepat dalam menyelesaikan soal. Berikut contoh hasil pekerjaanS27 yang melakukan kesalahan transformasi terdapat pada Gambar 3.

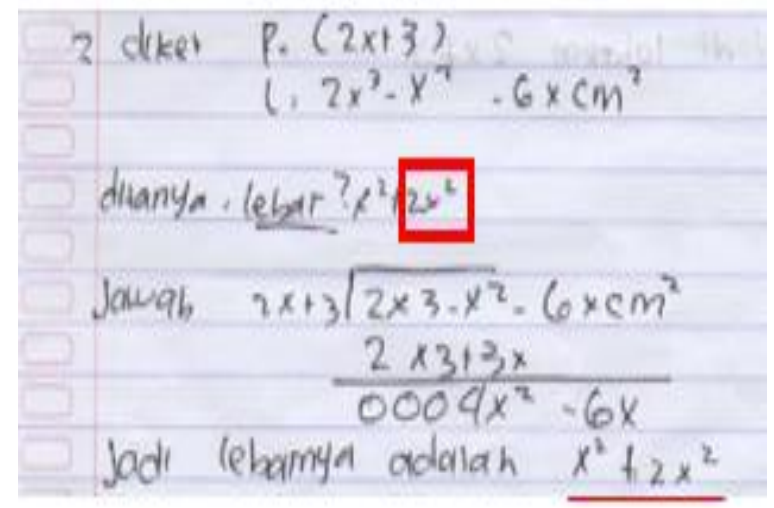

Gambar 3. Hasil Pekerjaan S27 Soal Nomor 2

Berdasarkan hasil pekerjaan S27 pada Gambar 3, menunjukkan bahwa S27 melakukan kesalahan transformasi, dimana S27 tidak menuliskan rumus yang akan digunakan dalam menyelesaikan masalah dalam soal.

\section{Kesalahan keterampilan poses}

Pada hasil tes 4 subjek penelitian menunujukkan adanya kesalahan keterampilan proses, diantaranya $\quad$ S2, S27, S21, dan S7 pada soal nomor 1, S27, S21, dan S7 pada soal nomor 2, S7 pada nomr 3. Hal tersebut telah dikonfirmasi dalam wawancara, diketahui subjek penelitian memang melakukan kesalahan ketrampilan proses karena tidak mengetahui prosedur atau langkah-langkah yang dibutuhkan dalam menyelesaikan operasi tersebut secara akurat, tidak menyelesaikan langkah-langkah dalam melakukan komputasi, dan siswa melakukan kesalahan dalam melakukan komputasi sehingga menghasilkan kesimpulan yang salah. Hasil ini sesuai dengan penelitian Trapsilasiwi, dkk (2016) bahwa kesalahan keterampilan proses yang dilakukan oleh siswa yaitu keslahan dalam melakukan komputasi. Hasil ini juga sesuai dengan penelitian Rahayuningsih, dkk (2014) bahwa kesalahan keterampilan proses terjadi karena siswa tidak dapat menentukan tahapan-tahapan yang akan dilakukan dan tidak dapat melakukan operasi hitung yang sesuai. Berikut contoh hasil pekerjaan siswa S7 yang melakukan kesalahan komputasi terdapat pada Gambar 4. 


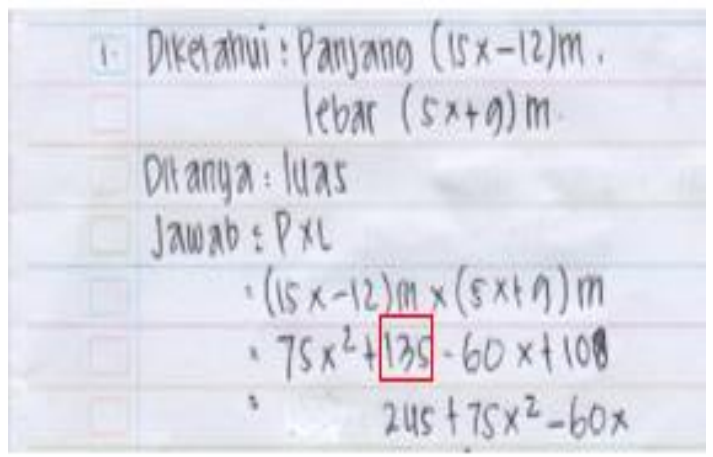

Gambar 4. Hasil Pekerjaan S7 Soal Nomor 2

Berdasarkan hasil pekerjaan S7 pada Gambar 4, menunjukkan bahwa S7 melakukan kesalahan pada komputasi, dimana $15 \mathrm{x} \times 9=135$ yang seharusnya $15 \mathrm{x} \times 9=135 \mathrm{x}$, sehingga jawaban akhir salah.

\section{Kesalahan penulisan jawaban}

Pada hasil tes 6 subjek penelitian menunujukkan adanya kesalahan penulisan jawaban, diantaranya S2, S5, S1, S27, S21, dan S7 pada soal nomor 1, S1, S27, S21, dan S7 pada soal nomor 2, S27, S21, dan S7 pada nomr 3. Hal tersebut telah dikonfirmasi dalam wawancara, diketahui subjek penelitian memang melakukan kesalahan penulisan jawaban karena siswa tidak menuliskan jawaban akhir tidak sesuai dengan kontesk soal, siswa tidak menuliskan kesimpulan akhir, menuliskan satuan tetapi salah, tidak menuliskan satuan dan tidak dapat menuliskan solusi secara tertulis dengan tepat. Hasil ini sesuai dengan penelitian Haryati, dkk (2015) bahwa kesalahan yang dilakukan siswa pada tahap penulisan jawaban akhir meliputi, siswa tidak membuat kesimpulan dan siswa membuat kesimpulan yang tidak tepat. Hasil ini juga sesuai dengan penelitian Fatahillah, dkk (2017) bahwa penyebab siswa melakukan kesalahan penulisan akhir meliputi, siswa tidak menuliskan kesimpulam, siswa menuliskan kesimpulan tetapi tidak sesuai dengan kontesk soal, kesalahan dalam menuliskan satuan. Hasil ini juga sesuai dengan penelitian Siswandi, dkk (2016) bahwa kesalahan penulisan jawaban akhir yang dilakukan siswa yaitu subjek tidak menuliskan satuan pada jawaban akhir dan tidak menuliskan kesimpulan dari jawabannya.

Berikut contoh hasil pekerjaan siswa S5 yang melakukan kesalahan penulisan jawaban terdapat pada Gambar 5.

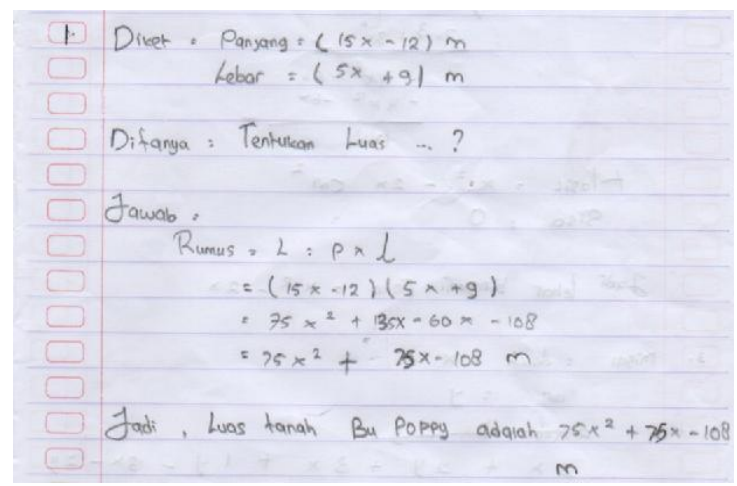

Gambar 5. Hasil Pekerjaan S5 Soal Nomor 1

Berdasarakan hasil pekerjaan S5 pada Gambar 5 menujukkan S5 melakukan kesalahan penulisan jawaban, terlihat S5 telah menuliskan jawaban akhir dan menuliskan kesimpulan, akan tetapi S5 salah dalam menuliskan satuan yang digunakan dimana S5 menuliskan satuan M, yang seharusnya M2 sehingga S5 di katakana melakukan kesalahan penulisan jawaban.

\section{KeSIMPULAN}

Pada analisis kesalahan siswa dalam menyelesaikan soal-soal materi operasi bentuk aljabar berdasarkan tahapan Newman, terdapat lima kesalahan yang dilakukan siswa yaitu sebesar $44.4 \%$, memahami soal sebesar $72.2 \%$, transformasi sebesar $44.4 \%$, ketrampilan proses sebesar $44.4 \%$, dan penulisan jawaban sebesar $77.8 \%$. Kesalahan yang dominan dilakukan oleh subjek penelitian adalah kesalahan memahami soal kesalahan penulisan jawaban. Faktor penyebabnya siswa melakukan kesalahan adalah tidak mengetahui kata kunciatau simbol yang ada pada soal, tidak menuliskan apa yang diketahui dan ditanya pada soal, tidak tidak dapat mengidentifikasi operasi atau menentukan rumus yang dibutuhkan untuk menyelesaikan permasalahan, melakukan kesalahan dalam komputasi, tidak menuliskan kesimpulan, tidak menuliskan satuan, dan menuliskan satuan tetapi tidak sesuai. 


\section{REFERENSI}

Amalia, R., Aufin, M., \& Khusiah R. 2018. Analisis Kesalahan dalam Menyelesaikan Soal Cerita pada Pokok Bahasan Persamaan Linier Berdasarkan Newman Kelas X-Mia di SMA Bayt Al-Hikmah Kota Pasuruhan. Prosiding SNMPM11, Prodi Pendidikan Matematika, Unswagati.

Andriani, T., Suastika, K., \& Sesanti, N.R. 2017. Analisis Kesalahan Konsep Matematika Siswa dalam Menyelesaikan Soal Trigonometri Kelas X TKJ SMKN 1 Gempol Tahun Pelajaran 2016/2017. Pi: Mathematics Education Journal 1 (1).

Fatahillah, A., Wati, F.Y., \& Susanto. 2017. Analisis Kesalahan Siswa dalam Menyelesaikan Soal Cerita Matematika Berdasarkan Tahapan Newman Beserta Bentuk Scaffolding yang diberikan. Jurnal Kadikma 8 (1).

Haryati, T., Suyitno, A., \& Junaedi, I. 2016. Analisis Kesalahan Siswa SMP Kelas VII dalam Menyelesaikan Soal Cerita Pemecahan Masalah Berdasarkan Prosedur Newman. Unnes Journal of Mathematics Education (UJME) 5 (1).

Hasibuan, I. 2015. Hasil Belajar Siswa Pada Materi Bentuk Aljabar Dikelas VII SMP Negeri 1 Banda Aceh Tahun Pelajaran2014/2015. Jurnal Peluang 4 (1).

Hudzaifah. 2013. Pembelajaran Fungsi Komposisi dan Fungsi Invers melalui Pendekatan Matematika Realistik untuk Meningkatkan Hasil Belajar Siswa SMA. Jurnal Pendidikan Sains 1 (4).

Islamiyah, A., Prayitno, S., \& Amruallah. 2018. Analisis Kesalahan Siswa SMP Pada Penyelesaian Masalah Sistem Persamaan Linear Dua Variabel. Jurnal Didaktik Matematika 5 (1).

Karnasih, I. 2015. Analisis Kesalahan Newman Pada Soal Cerita Matematis. Jurnal PARADIKMA 8 (1).

Kuswanti, Y., Sudirman., \& Nusantara, T. 2018. Deskripsi Kesalahan Siswa Pada Penyelesaian Masalah Sistem Persamaan Linear Tiga Variabel (SPLTV). Jurnal Pendidikan 3 (7).

Layn, M.R., Kahar, M.S. 2017. Analisis Kesalahan Siswa dalam Menyelesaikan Soal Cerita Matematika. Jurnal Math Educator Nusantara 3 (2).

Lusbiantoro, R. 2016. Kesalahan Siswa dalam Menyelesaikan Soal Ceita Berdasarkan Newman Erroranalysis Terkait Kemampuan Spasial. Prosiding Seminar Nasional Pendidikan Matematika. Semarang: UNISSULA PRESS.

Mulyadi, Slamet. 2018. Analisis Kesalahan Siswa Kelas dalam Menyelesaikan Soal Cerita Ditinjau dari Perbedaan Gender. Jurnal Program Studi Pendidikan Matematika 4 (1).

Oktaviana, D. 2017. Analisis Tipe Kesalahan Berdasarkan Teori Newman dalam Menyelesaikan Soal Cerita Pada Mata Kuliah Matematika Diskrit. Jurnal Pendidikan Sains \& Matematika 5 (2).

Rahayuningsih, P., Qohar, A. 2014. Analisis Kesalahan Menyelesaikan Soal Cerita Sistem Persamaan Linear Dua Variabel (SPLDV) Dan Scaffolding-Nya Berdasarkan Analisis Kesalahan Newman Pada Siswa Kelas VIII SMP Negeri 2 Malang. Jurnal Pendidikan Matematika Dan Sains II (2).

Romadiastri, Y. 2012. Analisis Kesalahan Mahasiswa Matematika dalam Menyelesaikan Soal-Soal Logika. Jurnal Phemenon 2 (1).

Rahmania, L., Rahmawati, A. 2016. Analisis Kesalahan Siswa dalam Menyelesaikan Soal Cerita Persamaan Linier Satu Variabel. Jurnal Matematika Dan Pendidikan Matematika 1 (2).

Rahmat, S. P. 2009. Penelitian Kualitatif. Jurnal Equilibrium 5 (9).

Siswandi, E., Sujadi, I., \& Riyadi. 2016. Analisis Kesalahan Siswa dalam Menyelesaikan Masalah Matematika Kontekstual Pada Materi Segiempat Berdasarkan Analisis Newman ditinjau dari Perbedaan Gender (Studi Kasus Pada Siswa Kelas VII SMPN 20 Surakarta). Jurnal elektronik pembelajaran matematika 4 (7).

Susanto, Ahmad. 2013. Teori Belajar dan Pembelajaran di Sekolah Dasar. Jakarta: Kencana Prenada Media Group.

Trapsilasiwi, D., setiawani, S., \& Ummah, K.I. 2016. Analisis Kesalahan Pengolahan Matematika dalam Menyelesaikan Masalah Lingkaran. Jurnal Pancaran 5 (4).

Visitasari, R., Siswono, T, Y. 2013. Kemampuan Siswa Memecahkan Masalah Berbentuk Soal Cerita Aljabar Menggunakan Tahapan Newman. Jurnal UNESA 8 (1).

Wijaya, A. A., dan Masriyah. 2013. Analisis Kesalahan dalam Menyelesaikan Soal Cerita Materi Sistem Persamaan Linier Dua Variabel. Jurnal Ilmiah Pendidikan Matematika 2 (1).

Copyright ( $) 2018$ Author [s]. This is an open-access article distributed under the terms of the Creative Commons Attribution License (CC BY). The use, distribution or reproduction in other forums is permitted, provided the original author(s) and the copyright owner(s) are cre dited and that the original publication in this journal is cited, in accordance with accepted academic practice. No use, distribution or reproduction is permitted which does not comply with these terms. 
White, A.L. 2010. Evaluasi Dari Analisis Permasalahan Newman. (online) Tersedia di (www.mav.vic.edu.au/files/comferences/2009/08White.pdf) diakses 17 september 2018.

Yanto, H. D., Karniasih, N,. \& Darmono, P. B. 2014. Eksperimen Model Pembelajaran Make A Match Dan Inside Outside Circle Pada Materi Bentuk Aljabar Siswa Kelas VIII. Ekuivalen- Jurnal Pendidikan Matematika 8 (1).

Yuirsa, K. Kriswandani. Budiono, I. 2016. Analisis Tipe Kesalahan Berdasarkan Teori Newman Pada Materi Statistic Bagi Siswa Kelas VII C SMP Kristen 02 Salatiga. Jurnal Portal Garuda 5 (1).

Yulia,R., Fauzi., \& Awaluddin. 2017. Analisis Kesalahan Siswa Mengerjakan Soal Matematika Dikelas V SDN 37 Bada Aceh. Jurnal IImiah Pendidikan Guru Sekolah Dasar 2 (1). 